\title{
EXAMINING THE EFFECT OF PRODUCT ASSORTMENT AND PRICE DISCOUNT TOWARD ONLINE PURCHASE DECISION OF UNIVERSITY STUDENT IN INDONESIA
}

\author{
Dita Amanah ${ }^{1 *}$, Dedy Ansari Harahap ${ }^{2}$ \\ ${ }^{1}$ Management Department, Universitas Negeri Medan, 20221, Indonesia \\ ${ }^{2}$ Management Department, Universitas Islam Sumatera Utara, Medan, 20219, Indonesia \\ *Corresponding author. Email: ditamnh@yahoo.com
}

\begin{abstract}
This study investigated the effect of product assortment and price discount on online purchase decision among university student in Indonesia. Ninety samples were employed which is students who had made an online purchase for fashion products. Purposive sampling has been applied as a sampling technique in this study. The results revealed that product assortment affected significantly to student online purchase decision. However, price discount did not affect significantly to online purchase decision. The limitation is only to test two variables of price discount and product diversity. Further studies are encouraged to consider other variables in determining online purchasing decisions such as trust, reputation, attractiveness of posting messages.
\end{abstract}

Keywords: Price discount, product assortment, online purchase decision, university student.

\section{Introduction}

The competition between online stores is getting tougher. Evidently the number of emerging online stores that come from large companies and retailers who switch to digital business. They offer a variety of products to meet the needs of consumers. The number of e-Commerce will continue to increase, this is reinforced by a number of surveys of domestic and foreign information communication technology research institutions. Aulia E Marinto, Chairman of the Indonesian E-Commerce Association (idEA), stated that the 2016 Economic Census Data from the Central Bureau of Statistics (BPS) stated that the e-commerce industry in the last ten years grew by about seventeen percent with the total number of e-Commerce reached 26.2 million units.

Meanwhile, Global Research from Bloomberg states, in 2020 more than half of Indonesia's population will be involved in e-Commerce activities. McKinsey said in a report titled Unlocking Indonesia's Digital Opportunity also said the switch to digital would boost economic growth to $\$ 150$ billion by 2025 . The report also said 73 percent of internet users in Indonesia access the internet via mobile devices. This figure is expected to continue to grow in the next five years.

"The massive use of smart phones is also one of the supporting factors for the growth of e-Commerce industry in Indonesia," said Aulia. Director of Digital \& Strategic Portfolio Telekomunikasi Indonesia
(Persero), Tbk. (Telkom), David Bangun added, eCommerce is currently so massive requires the support of a strong and extensive infrastructure. This is one of Telkom's responsibility as a State-Owned Enterprise (BUMN) in telecommunication. David said that Telkom continues to support the acceleration of Indonesia's digital economy through various digital products such as Blanja.com and Melon. Telkom also synergize with other SOEs in enhancing the growth of digital economy by holding the built work (Ricky, 2017).

Companies need to formulate appropriate strategies to attract the attention of consumers making purchases. Strategy formulation is not easy because consumers have different shopping goals and they have many shopping options to meet their needs. Especially in the digital era today, everyone can make purchases online by utilizing gadget technology such as mobile phones, computers, laptops and so on. Online purchases are purchases made by consumers via the internet (Varma \& Agarwal, 2014). Consumers can make purchases from anywhere and obtain complete information about products such as price, size, color and product availability (Solomon, RusselBennet, \& Previte, 2013). Therefore, to obtain customers, online marketers perform various strategies such as website links, banner ads and e-mail spamming (Hollensen, 2015).

One strategy that marketers can apply is to equip a store with a variety of products that fulfill consumer needs. Kotler and Keller (2016a) states that the pro- 
duct assortment is the availability of various types of products offered by marketers to be owned or consumed by consumers. Product assortment is the completeness of the products include the depth, breadth and quality and also availability of products at any time desired consumer. To develop product assortment, marketers must understand the purpose of consumer purchases (Pride \& Ferrell, 2015).

Variations and presentation of products in the store are important in addressing the diversity of products that will create different consumer perceptions of the product and will trigger higher consumption (Hoyer \& MacInnis, 2010). Product diversity is closely related to consumer behavior in making purchasing decisions (Kotler, 2010).

Product assortment provides benefits for the store, such as to provide satisfaction for consumers. The more complete the product available in a store, the more it will make consumers feel satisfied (Lancaster, 1990); Jeong \& Lee, 2010). Another benefit is to offer more variety to consumers (Broniarczyk, Hoyer, \& McAlister, 1998), decision flexibility (Kahn \& Lehmann, 2015); (McAlister, 1982), and gives consumers the freedom to choose products (Aubry, 2012).

The more varied products offered by marketers will be more satisfied consumers make purchases at the store and will affect further purchase (Tjiptono, $2012 b)$. So the diversity of products is the depth and narrow assortment, deep and wide assortment, shallow and narrow assortment, shallow and wide assortment (Gilbert, 2003); (Omar, 1999).

In addition to product diversity, another factor that is not less important for consumers in purchasing is price. Today, consumers are very sensitive to price. Consumers will more easily accept a product when the price is affordable. Pricing is tailored to the quality, price competition and product benefits. Price is money or other considerations (products and services) exchanged to obtain or use the product or service. Price is an indicator of the value of a product. High product value if the benefits received by consumers is greater than the price. Conversely, if the price is more expensive than the benefits of the product then the value is low. Overall the price will contribute profits to the company (Kerin \& Hartley, 2017). For consumers, the price is the cost incurred to buy the product. Marketers need to find ways to set prices that can create greater customer value. Price is a consumer sacrifice in exchange for obtaining a product or service that also plays two roles in the evaluation of product selection as a measure of sacrifice and as an information cue. Thus, realistic pricing will determine the effectiveness of corporate strategy (Lamb, Hair, \& McDaniel, 2017).

Most marketers use discounted prices as a stimulus for consumers. The discounted price is a price reduction from the normal price of the product that the company offers (Perreault, Cannon, \& McCarthy, 2017). The discounted price is one of the most preferred strategies of consumers. Each online store competes to offer products at discounted prices in order to satisfy consumers, increase purchases and also add new customers. Implementation of drastically discounted prices will indeed increase sales but will undermine brand loyalty (Kotler \& Keller, 2016b).

The price discount is a direct reduction of the price of the goods during a period of time specified by the seller (Kotler, 2010) and is a seller's appreciation to the buyer of a particular buyer's pleasant activity for the seller (Tjiptono, 2012a). The goal of price discounts is to encourage buyers to shop in huge, add / retain customers, attract attention (Schiffman \& Kanuk, 2010). Marketers can apply various ways of price discounts such as discounted cash prices, quantity discounts, functional price discounts, seasonal discounts, price discounts (correlr Marketers can apply various ways of price discounts such as discounted cash prices, quantity discounts, functional price discounts, seasonal discounts, price discounts (Kotler \& Armstrong, 2014).

Respondents in this study focused on doctoral students at the Universitas Pendidikan Indonesia who had shopping online. Based on this phenomenon then we develop the following hypothesis:

$H_{l}$ : There is a significant effect of product assortment on online purchasing decisions.

$\mathrm{H}_{2}$ : There is a significant effect of price discount on online purchasing decisions.

\section{Research Method}

The aim of this study was to investigate the influence of product assortment and price discount on online purchase decision of university students. The questions asked in this study are:

1. How does the product assortment affect online purchasing decisions?

2. How does the price discount affect online purchasing decisions?

3. Which is more influential on online purchasing decisions, product assortment or price discount?

This study has a conceptual framework as presented in Figure 1. 


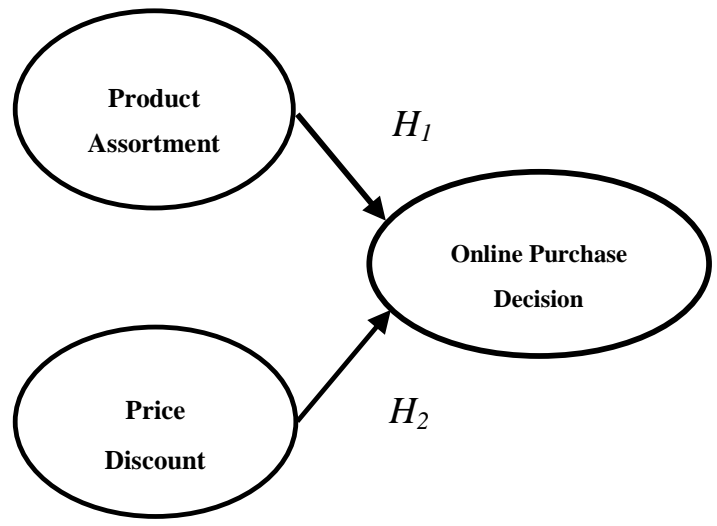

Figure 1. Conceptual framework

Product assortment is an assessment of the completeness of the product provided by a store, with indicators are the product brand variation, product variation, product size variation, product quality variation (Utami, 2010).

Price discount is one of the marketing strategy that reduces the price list provided by the seller to a buyer who benefits both buyers and sellers (Perreault et al., 2017). The indicators are the frequency, type, discount amount offered by the seller (Kotler \& Armstrong, 2016).

Purchase decision is a decision that consumers take to buy a certain product after going through several stages. The indicators are product choice, brand choice, dealer choice, purchase amount, purchase time, payment method (Kotler \& Keller, 2016a).

Ninety questionnaires received from student of Doctoral Program of Management Science of Universitas Pendidikan Indonesia with purposive sampling as a sampling technique. The purposive sampling technique in this study is addressed to doctoral students who have had experience of online shopping as already stated in the introduction of this paper.

We were used multiple linear regression method to analyzed the data that has been collected. For measuring the effect of each independent variable and also the simultaneous influence to the dependent variable, we were used the $t$ test. Then to predict the contribution of independent to dependent variable we were used $R^{2}$ test.

\section{Result and Discussion}

Product assortment was a major consideration in the students online purchasing. This is shown in the $t$ test result is 10.559 which is much greater than 1.987 . Otherwise, in the $t$ test of price, the result is 1.068 , which is far smaller than 1.987. This means prices have an effect but not significant on online purchasing decisions for fashion products among university students. They are doctoral degree students who are shopping online. For them, prices do not become so important in purchasing products because all doctoral students have worked and already have income. They prefer the choice of many products offered by online stores so they are more flexible to choose the desired product. Price is not a problem for them as long as fashion products are purchased in accordance with contemporary style and taste. Therefore, the result of regression analysis is $Y=1.037+0.069 X_{1}+0.635 X_{2}$ $+e$. These mean that if product assortment and price discount do not exist, then the online purchase decision is 1.037. Any increase of one unit of product assortment, will affect online purchase decision of 0.635 . For the price discount, any increase of one rupiah will affect online purchase decision of 0.069 . All assuming other factors are constant. All results are presented in Table 1.

The regression equation has $F$ test result, which is 61.179. It is much larger than 3.10. This equation is significant. Results are shown in Table 2.

The coefficient determination $\left(R^{2}\right)$ is 0.584 , means $58.4 \%$ online purchase decision among university students explained by product assortment and price discount. The rest of $41.6 \%$ explained by others out of this study (Shown in Table 3).

This study found that partially product assortment and price discounts influence the online purchasing decisions of students. This result is supported by Amanah, Harahap, \& Lisnawati (2017) stating that student online purchasing decisions at Universitas Negeri Medan, Indonesia are influenced by product diversity. The result of $t$ test of product diversity was 10.204. Also in line with Gao and Simonson (2016) who found that the addition of the number of products to complement the in-store product has a more positive effect on the consumer's propensity to buy the product. That is, consumers will prefer stores that have a complete product rather than an incomplete because it can facilitate consumers to choose and meet the shopping goals. The depth and breadth of the products that certain stores offer will greatly affect consumers' perceptions of the store and will further influence the consumer's decision to buy at the store (Aspfors, 2010).

Consumer choices on diverse products are influenced by costs. Consumers can therefore deselect in an effort to minimize their desires and also reduce the level of consumptive. Diverse products will increase consumer awareness in choosing products and consumers will choose products that truly optimize their decisions. Consumers are found to be more 
interested in a complete product and according to their preferences (Chernev, 2011). The number of choices consumers face can affect not only whether they choose but also what they choose. Choosing from many different types of options tends to increase the difficulty and consequently leads consumers to rely more on easy-to-obtain justification in making a choice (Sela, Berger, \& Liu, 2009). Product variation directly affects consumer choice by the consumer and is indirectly influenced by product lines offered by the seller through product quality as intervening variable (Berger, Draganska, \& Simonson, 2007). For international marketers, cultural diversity should be a consideration in creating product diversity. Therefore, marketers should develop knowledge about the characteristics of consumers to meet an ever-increasing need (Ahmed, Uddin, \& Ahshanullah, 2009). the completeness of existing products in the store will also create consumer perceptions of product and store quality. The results of this study are also supported by Chernev and Hamilton (2009), which states that consumer interest in the store depends on the size of the completeness of the product provide by the store. The more complete the product provided the more interested consumers will be to shop at the store. Product completeness can also affect buyer preferences and consumer purchase decisions on multiple product line options that the store offers. The more complete the product line provided, the more likely it will affect and convince consumers to buy in that store (Müller, Kroll, \& Vogt, 2009).

The second finding in this study is the influence of price discounts on online purchasing decisions. Based on Isabella, Pozzani, Chen and Gomes (2012), consumers will be more interested in stores that charge big discounts than small price discounts. They compare between two different price discounts (small and large) addressed to the consumer to know their buying intentions. This in line with Faryabi, Sadeghzadeh, \& Saed (2012) who found that The discounted price positively affects the store image and so on positively affects the consumer's online purchase. Therefore, online marketers should develop effective marketing plans and promotional approaches to create a more positive store image that will attract more consumers and so will increase their online store sales.

Price sensitivity is higher in online purchases, because online promotion becomes a stronger discounted price signal. The lower the price offered online store, it will increasingly attract consumers to shop online. Conversely, expensive prices will cause consumers less interested in shopping. The influence of price and promotion on product selection is weaker online compared to offline shopping (Degeratu, Rangaswamy, \& Wu, 2000).

Table 1

The $t$ Test and Regression Analysis Result

\begin{tabular}{|c|c|c|c|c|c|c|c|c|}
\hline & \multirow[t]{2}{*}{ Model } & \multicolumn{2}{|c|}{$\begin{array}{c}\text { Unstandardized } \\
\text { Coefficients }\end{array}$} & $\begin{array}{c}\text { Standardized } \\
\text { Coefficients }\end{array}$ & \multirow[b]{2}{*}{$t$} & \multirow[b]{2}{*}{ Sig. } & \multicolumn{2}{|c|}{ Collinearity Statistics } \\
\hline & & $B$ & Std. Error & Beta & & & Tolerance & $\overline{V I F}$ \\
\hline \multirow[t]{3}{*}{1} & (Constant) & 1.037 & .292 & & 3.548 & .001 & & \\
\hline & Product Assortment & .635 & .060 & .746 & 10.599 & .000 & .963 & 1.038 \\
\hline & Price Discount & .069 & .064 & .075 & 1.068 & .288 & .963 & 1.038 \\
\hline
\end{tabular}

a. Dependent Variable: online purchase decision

Table 2

The $F$ Test Result ANOVA ${ }^{a}$

\begin{tabular}{rlrrrrr}
\hline & Model & Sum of Squares & Df & Mean Square & $\boldsymbol{F}$ & Sig. \\
\hline 1 & Regression & 9.730 & 2 & 4.865 & 61.179 & $.000^{\mathrm{b}}$ \\
& Residual & 6.919 & 87 & .080 & & \\
Total & 16.649 & 89 & & & \\
\hline
\end{tabular}

a. Dependent Variable: online purchase decision

b. Predictors: (Constant), product assortment, price discount

Table 3

The Coefficient Determinant Test Result (Model Summary ${ }^{b}$ )

\begin{tabular}{rrrrr}
\hline Model & $\boldsymbol{R}$ & $\boldsymbol{R}$ Square & Adjusted R Square & Std. Error of the Estimate \\
\hline 1 & $.764^{\mathrm{a}}$ & .584 & .575 & .28200
\end{tabular}

a. Predictors: (Constant), product assortment, price discount

b. Dependent Variable: online purchase decision 
Other study that support this research is (Kim, Bojanic, \& Warnick, 2009). The aim of their research is to find out whether bundling pricing practices by online travel agents result in actual monetary savings for consumers (i.e. lower prices) relative to prices charged by individual service providers (i.e. hotels and airlines) through their own online website. The results indicate that there is lower monetary savings in the form of lower prices realized to consumers who purchase combined offerings from online travel agents, and there is an interaction effect between the channel and the hotel class. Also consistent with $\mathrm{Xu}$ and Huang (2014) where the discounted price results in an online impulse purchase greater than the bonus package when the product is hedonic, and the bonus package is a more effective sales promotion than the discounted price for a utilitarian product. In addition, discounted prices result in larger online impulse purchases compared to bonus packages for cheap products, while bonus packages are more effective sales promotions than discounts on expensive products. Discount strategies applied by online stores may be different, as Ma, Lin, and Zhao (2016) states, that discounts are tailored to the profit margin to be gained and also based on consumer expectations. Online stores implement this discount strategy for fear of losing consumers where competition among online stores is so fierce today that each implementing various strategies to retain customers.

Results of this study are not in line with Kim, $\mathrm{Xu}$, and Gupta (2012) which states that the trust of online stores is stronger than the price. However, prices have a stronger influence on purchasing decisions for regular customers than with potential customers. In contrast, consumer confidence has a stronger impact on potential customers than with regular customers.

\section{Conclusions}

The study attempts to explain the effect of product assortment and price discount on online purchase decision among university students at Universitas Pendidikan Indonesia. The results indicate that the product assortment significantly affects the students online purchasing decisions, while prices are not. Price discounts effected but not significantly on online purchase decision among university students.

\section{Implications}

Online marketers should focus more on product assortment because more diversity and complete of products offered by online stores will further influence the online purchasing decisions. This study is also expected to help the online marketers to develop their products and provide more varied products and also evaluate the existing price on their products.

\section{References}

Ahmed, S. F, Uddin, M. M., \& Ahshanullah, M. (2009). Consumers' reaction to product variety: Does culture matter? International Business Research, 2(3), 115-120.

Amanah, D., Harahap, D. A., \& Lisnawati, D. (2017). Exploring online purchase decision among university students in Indonesia. Journal of Humanities and Social Science, 22(5), 72-77.

Aspfors, E. (2010). Customer perception of service, store image and product assortment - from an interior store perspective. Thesis. Vaasa University of Applied Sciences. Swedish.

Aubry, A. (2012). The effect of product diversity on the pattern of consumption. Preliminary Work. Belgium.

Berger, J., Draganska, M., \& Simonson, I. (2007). The influence of product variety on brand perception and choice. Marketing Science, 26(4), 460-472.

Broniarczyk, S. M., Hoyer, W. D., \& McAlister, L. (1998). Consumers' perceptions of the assortment offered in a grocery category: The impact of item reduction. Journal of Marketing Research, $X X X V$ (May), 166-176.

Chernev, A. (2011). Product assortment and consumer choice: An Interdisciplinary review by Alexander Chernev. Foundations and Trends in Marketing, 6(1), 1-61.

Chernev, A., \& Hamilton, R. (2009). Assortment size and option attractiveness in consumer choice among retailers. Journal of Marketing Research, XLVI (June), 410-420.

Degeratu, A. M., Rangaswamy, A., \& Wu, J. (2000). Consumer choice behavior in online and traditional supermarkets: The effects of brand name, price, and other search attributes. International Journal of Research in Marketing, 17(1), 55-78.

Faryabi, M., Sadeghzadeh, K., \& Saed, M. (2012). The effect of price discount $\mathrm{s}$ and store image on consumers' purchase intention in online shopping context case study: Nokia and HTC. Journal of Business Studies Quarterly, 4(1), 197205.

Gao, L., \& Simonson, I. (2016). The positive effect of assortment size on purchase likelihood: The moderating influence of decision order. Journal of Consumer Psychology, 26(4), 542-549.

Gilbert, D. (2003). Retail marketing management. New Jersey: Prentice Hall. 
Hollensen, S. (2015). Marketing management. (3rd Ed.). United Kingdom: Pearson Education Limited.

Hoyer, W. D., \& MacInnis, D. J. (2010). Consumer behavior. (5th Ed.). Mason: Cencage Learning.

Isabella, G., Pozzani, A. I., Chen, V. A., \& Gomes, M. B. P. (2012). Influence of discount price announcements on consumer's behavior. Revista de Administração de Empresas, 52(6), 657-671.

Jeong, Y., \& Lee, Y. (2010). A study on the customer satisfaction and customer loyalty of furniture purchaser in on-line shop. The Asian Journal on Quality, 11(2), 146-156.

Kahn, B. E., \& Lehmann, D. R. (2015). Modelling choice among assortments. Journal of Retailing, $1-26$.

Kerin, R. A., \& Hartley, S. W. (2017). Marketing. New York: McGraw Hill Education.

Kim, J., Bojanic, D. C., \& Warnick, R. B. (2009). Price bundling and travel product pricing practices used by online channels of distribution. Journal of Travel Research, 47(4), 403-412.

Kim, H. W., Xu, Y., \& Gupta, S. (2012). Which is more important in Internet shopping, perceived price or trust? Electronic Commerce Research and Applications, 11(3), 241-252.

Kotler, P. (2010). Principles of marketing: A South Asian perspective. $\left(13^{\text {th }}\right.$ ed.). New Jersey: Pearson Education.

Kotler, P., \& Armstrong, G. (2014). Marketing: An introduction (Global Edition). New Jersey: Pearson Education Limited.

- (2016). Principles of marketing. (16 ${ }^{\text {th }}$ Ed.). England: Pearson Education Limited.

Kotler, P., \& Keller, K. L. (2016a). A framework for marketing management. ( $6^{\text {th }}$ Ed.). England: Pearson Education Limited.

(2016b). Marketing management. (Global Edition $15^{\text {th }}$ Ed.). England: Pearson Education Limited.

Lamb, C. W., Hair, J. F., \& McDaniel, C. (2017). Principles of marketing. USA: Cengage Learning.

Lancaster, K. (1990). The economics of product variety: A survey. Marketing Science, 9(3), 189 206.

Ma, S., Lin, J., \& Zhao, X. (2016). Online store discount strategy in the presence of consumer loss aversion. International Journal of Production Economics, 171, 1-7.
McAlister, L. (1982). A dynamic attribute satiation model of variety-seeking behavior. Journal of Consumer Research, 9(2), 141-150.

Müller, H., Kroll, E. B., \& Vogt, B. (2009). How product assortments affect buyer preferences: Empirical analysis of the robustness of the compromise effect. FEMM Working Paper No. 31, October 2009. University Magdeburg. Germany.

Omar, O. (1999). Retail marketing. Essex: Pearson Education Limited.

Perreault, W. D., Cannon, J. P., \& McCarthy, J. E. (2017). Essentials of marketing: A marketing strategy planning approach. (15 ${ }^{\text {th }}$ ed.). New York: McGraw Hill Education.

Pride, W. M., \& Ferrell, O. C. (2015). Foundations of marketing. $\left(6^{\text {th }}\right.$ Ed.). USA: Cengage Learning.

Ricky, P. D. M. (2017). Belanja online: Pertumbuhan transaksi e-commerce Indonesia tertinggi dunia. Retrieved April 11, 2018, from http://www. jatengpos. com/2017/08/belanja-online-pertumbuhan-transaksi-e-commerce-indonesia-tertinggidunia-842189.

Schiffman, L. G., \& Kanuk, L. L. (2010). Consumer behavior. (10th ed.). New Jersey: Pearson Education.

Sela, A., Berger, J., \& Liu, W. (2009). Variety, vice, and virtue: How assortment size influences option choice. Journal of Consumer Research, 35(6), 941-951.

Solomon, M. R., Russel-Bennet, R., \& Previte, J. (2013). Consumer behaviour: Buying, having, being. (3rd Ed.). Australia: Pearson Australia Group.

Tjiptono, F. (2012a). Pemasaran strategik. Yogyakarta: Andi.

(2012b). Strategi pemasaran. Malang: Bayu Media Publishing.

Utami. (2010). Konsep pemasaran. Jakarta: PT. Indeks.

Varma, I. G., \& Agarwal, M. R. (2014). Online buying behaviour of homemakers in Western Suburbs of Mumbai and social media influence. IOSR Journal of Business and Management, 16 (8), 42-65.

Xu, Y., \& Huang, J.-S. (2014). Effects of price discounts and bonus packs on online impulse buying. Social Behavior and Personality, 42(8), 1293-1302. 